PRODUCTION

ENGINEERING

ARCHIVES
2013, Vol. 3, No 2, pp 22-25

ISSN 2353-5156 (print version)

ISSN 2353-7779 (online version)

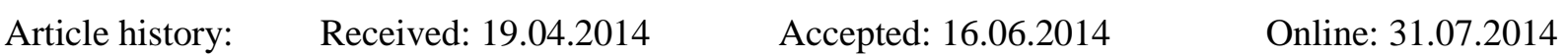

\title{
Quality analysis during production of car counter cases
}

\author{
Marta Jagusiak-Kocik ${ }^{1}$ \\ ${ }^{1}$ Institute of Production Engineering, Faculty of Management, Czestochowa University of Technology, Armii Krajowej 19B, 42-201 \\ Czestochowa, Poland
}

Abstract. In the chapter the company operating in the plastic industry was presented. The car counter case to Fiat was the main subject. The production process of the research product depicted technologically was presented. Hierarchy of the nonconformities with use of ParetoLorenz diagram was made.

Key words - plastic industry, the car counter case, the production process depicted technologically, nonconformity, Pareto-Lorenz diagram

\section{Characteristics of the research object and subject}

The subject of the research is a company operating since 1985 in the printing market, and since 2003 in the plastics processing industry. The company has been engaged in a comprehensive printing and design service for other companies and institutions. It mainly deals with offset printing, pad printing and screen printing.

Additional services handled by the research company include: milling of the parts, mounting holes with use of a CNC milling plotter, ultrasonic welding, own tool and managing of projects from beginning to the moment of official certificate of detail, assembly, testing at the customer's request, trial production, implementation of new raw materials and test overspray. In addition, the company also offers painting of details and printing on the metallized details. It also ensures proper lightening of the mapped color samples. It also of- fers performance of a wide range of graphic design of the manufactured products from standard to 3D.

The company performs printing on the details of various plastics, including ABS, PVC, PC, PS, PP, PE, with the technique of screen printing and pad printing. These are usually flexible details for manufacturers of household appliances, such as control panels and knobs for washing machines, dishwashers, dryers for clothes, cookers, and the automotive industry. More than 20 years of experience allows the company to implement printing on the most complex detail in terms of shape and used materials.. It is possible to use a variety of dimensions and the number of colors on the individual mop with patterns for color. The company, to meet the expectations of customers, performs unusual work.

One chosen product - a car counter case of Fiat was analyzed. The car counter is produced by injection molding to the molds, to different car models. This car counter case consists of several elements which are 
housing, gasket, felts and fastening pins. All these elements are mounted by machine operators after exiting of the case from the injection mold machine. The mounter car counter cases are taken to the Department of Printing, where after being printed and $100 \%$ controlled are packed and sent to customers.

\section{Production process depicted techno- logically}

The production process of the car counter cases to Fiat, depicted technologically, is presented in Figure 1.

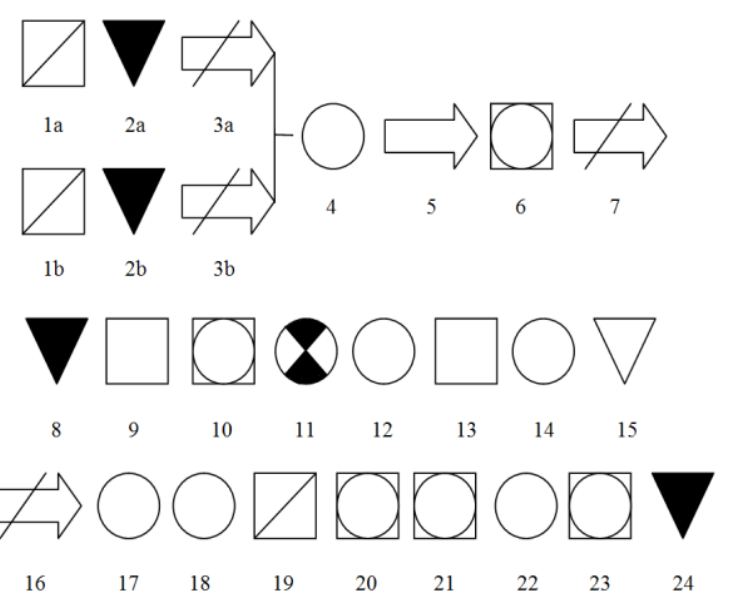

Fig. 1. Scheme of Production process of the car counter cases to Fiat depicted technologically.

Source: own study.

Characteristics of the individual steps of the production process (BORKOWSKI S., INGALDI M., JAGUSIAK-KOCIK M. 2013., BORKOWSKI S., ULEWICZ R. 2008., BURCHART-Korol D., FURMAN J. 2007., DURLIK I. 1993):

1a. Initial control of the granulate, in this case copolymer of the propylene and ethylene P/E type EP 340, EP 3342R or polipropylene HP 500.

1b. Initial control of the dye.

Quality control Department checks correctness of the supply. Verification is conducted in accordance with the proper procedure. In case of compliance, material is released to production process - a label with information about the provider, delivery time and the person releasing the raw material for the production, is glued.

2a. Storage of the plastic in the form of granulate.

2b. Storage of the dye.
The warehouse has air-conditioning and this is placed close to the production hall.

3a. Transport of the granulate from the warehouse to the mixer with forklift.

3b. Transport of the dye from the warehouse to the mixer with forklift.

4. Mixing of the proper ingredients of the granulate, dye in the mixer in proper proportions.

5. Inter-operation transport of the ready mixture to the injection moulding machine with the lift.

6. Injection moulding of the plastic to the form of the injection moulding machines and control. A person working at the injection moulding machine checks the quality of the cast (whether there is any kind of discoloration, pigmentation of the cast, scorch, flaws or shortcoming in joining the cast). If there is no obvious problem, the workers start the assembly. If there is any nonconformity noticed, the product is sent to the mixer, where it is mixed and then recycled in the production process.

7. Transport of the nonconforming products to the waste warehouse by low manual lift pallet truck.

8. Waste warehouse and mixer.

9. Quality Control measurements of the hardness and thickness of the material, the percentage composition of the dye.

10. Manual processing of 10 holes, trimming and milling by workers connecter with visual control.

11. Installation of the gasket with 12 pins which mounting gasket and 2 pieces of the felt to the hooks of the cover.

12. Labelling of each piece with a description of installation date and worker number.

13. Quality Control of proper execution of assembly.

14. Packing of 84 pieces in plastic containers by the workers.

15. Intermediate storage of the car counter cases under the umbrella roof at the production floor. After proper number of product execution the car counter cases are loaded on the truck by high lift truck.

16. Transportation to the Department of Printing.

17. Unpacking and lining of the car counter cases on the dryer by packer and printer operator.

18. Setting up of the design in accordance with the official certification of the car counter cases, after preparation of the paint in appropriate proportions (45 $\mathrm{g}$ of paint and $6 \mathrm{~g}$ of solvent). 
19. Inspection of the setting up of the design, printing position in accordance with the official certification, visual control of the car counter cases to avoid nonconformities overlooked during previous operations.

20. Printing and visual control of the print by printer operator and control of the paint and its pouring.

21. Packing (with visual control) in plastic containers. 22. Labelling of containers by packing workers after checking by quality control workers, the contents of the container, code compliance and the imposition of stamp on the label.

23. Tests on adhesion of the paint made by quality control workers after appropriate time. Tests are carried out after a few or even several hours, according to the paint manufacturer's recommendations.

24. Storage of the final products in the storage hall located next to the production hall.

After a short period of storage of the final products, these products are sent to the recipient client.

\section{Hierarchy of the nonconformities with use Pareto-Lorenz diagram}

Pareto-Lorenz diagram (BORKOWSKI S. 2004, BORKOWSKI S. 2012., HAMROL A. 1998, INGALDI M., JAGUSIAK-KOCIK M. 2013) belongs to the traditional tool of quality management and is based on the regularity that typically $20-30 \%$ of the causes decided by about $70-80 \%$ of the effects. It allows for identification and prioritization of the most important causes, events causing an effect and to identify action which should improve the level of processes and the quality of products and services.

Analysis of the nonconformities during production process of the car counter cases to Fiat, with the use of the Pareto-Lorenz diagram, was conducted within a month. The aim of the analysis was to identify nonconformities that occur most frequently and are the cause of loss, and that should be removed or reduced as the first.

During the research period 10 different kinds of nonconformities causes were identified:

- $\quad \mathrm{N} 1$ - inclusions (83 pc),

- $\mathrm{N} 2$ - discolorations (127 pc),

- $\quad \mathrm{N} 3$ - scorch (109 pc),

- $\mathrm{N} 4$ - greasy stains (42 pc),
- $\quad \mathrm{N} 5$ - misrun casting (7 pc),

- N6 - fallings (14 pc),

- $\quad$ N7 - fracture of the connecting line (2 pc),

- $\quad \mathrm{N} 8$ - bad trimming $(5 \mathrm{pc})$,

- $\mathrm{N} 9$ - scratches $(65 \mathrm{pc})$,

- $\mathrm{N} 10$ - bad position of the overprint (26 pc).

The nonconformities occurring during the production process of the car counter cases to Fiat were ranked according their occurrence frequency. Percentage fractions and cumulated fractions of these nonconformities were presented in Table 1.

Table 1. Hierarchy of the nonconformities of the car counter cases to Fiat

\begin{tabular}{|c||c||c||c|}
\hline $\begin{array}{c}\text { Denotation } \\
\text { of the causes }\end{array}$ & Name of the causes & $\begin{array}{c}\text { Percentage } \\
\text { fraction }\end{array}$ & $\begin{array}{c}\text { Cumulated } \\
\text { fraction }\end{array}$ \\
\hline \hline $\mathrm{N}_{2}$ & discolorations & 26.46 & 26.46 \\
\hline $\mathrm{N}_{3}$ & scorch & 22.71 & 49.17 \\
\hline $\mathrm{N}_{1}$ & inclusions & 17.29 & 66.46 \\
\hline $\mathrm{N}_{9}$ & scratches & 13.54 & 80.00 \\
\hline $\mathrm{N}_{4}$ & greasy stains & 8.75 & 88.75 \\
\hline $\mathrm{N}_{10}$ & $\begin{array}{c}\text { bad position of the } \\
\text { overprint }\end{array}$ & 5.42 & 94.17 \\
\hline $\mathrm{N}_{6}$ & fallings & 2.92 & 97.08 \\
\hline $\mathrm{N}_{5}$ & misrun casting & 1.46 & 98.54 \\
\hline $\mathrm{N}_{8}$ & bad trimming & 1.04 & 99.58 \\
\hline $\mathrm{N}_{7}$ & $\begin{array}{c}\text { fracture of the } \\
\text { connecting line }\end{array}$ & 0.42 & 100.00 \\
\hline
\end{tabular}

Source: own study

On the basis of the data presented in Table 10.1 Pareto-Lorenz diagram was created and presented in Figure 2.

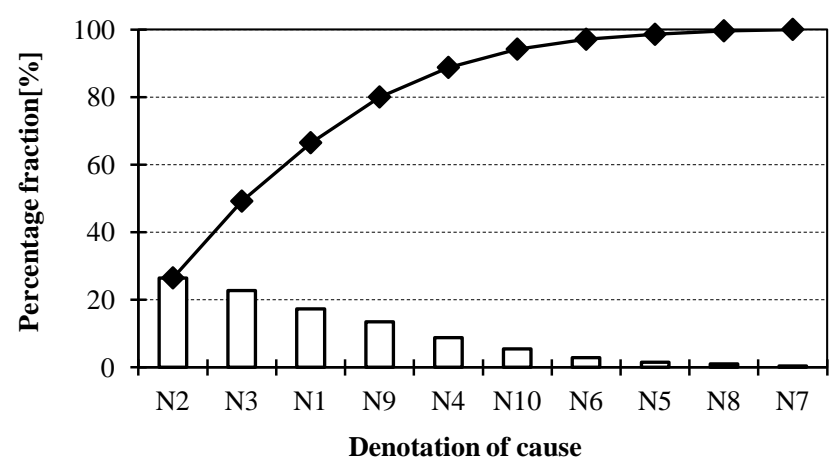

Fig. 2. Pareto-Lorenz diagram for the analysis of the nonconformities of the car counter cases to Fiat.

Source: own study

From the diagram presented in Figure 2 it appears that $30 \%$ of all causes influence $66.46 \%$ of results. Moreover, it can be concluded that for $66,64 \%$ nonconformities occurring during the production 
process of the car counter cases to Fiat, 3 causes are responsible: $\mathrm{N}_{2}$ (discolorations), $\mathrm{N}_{3}$ (scorch) and $\mathrm{N}_{1}$ (inclusions). The remaining 7 causes are responsible for $33.54 \%$ results.

\section{Summary}

The Pareto-Lorenz diagram was created to identify nonconformities of the car counter cases that occur most frequently and are the cause of loss, and that should be removed or reduced as the first. It was found that the most important nonconformity was discoloration. This problem stems from improper cleaning of the machine and it should be eliminated as the first.

\section{Bibliography}

1. Borkowski S. 2004. Mierzenie Poziomu Jakości. Publisher WSZiM, Sosnowiec.

2. BORKOWSKI S. 2012. Tradycyjne narzędzia zarządzania jakościa. Teoria i praktyka. Ofic. Wydawnicza Stowarzyszenie Menedżerów Jakości i Produkcji (SMJiP). Częstochowa.

3. BORKOWSKI S., ULEWICZ R. 2008. Zarządzanie produkcja. Systemy produkcyjne. Oficyna Wydawnicza „Humanitas". Sosnowiec.

4. BURChART-Korol D., FURMAn J. 2007. Zarzqdzanie produkcja i ustugami. Wydawnictwo Politechniki Śląskiej. Gliwice.

5. DURLIK I. 1993. Inżynieria zarządzania. Strategia $i$ projektowanie systemów produkcyjnych. Agencja Wydawnicza Placet. Gdańsk.

6. HAMrol A. 2008. Zarzadzanie jakościa z przyktadami, wydanie 2. Wydawnictwo PWN. Warszawa.

7. INGALDI M., JaGUSIAK-KociK M. 2013. Analysis and quality Improvement In the dairy products manufacturing company. Chapetr 4. [In:] Toyotarity. Technologies Management. BORKOWSKI S., KLIMECKA - TATAR D. (Ed.). Savas Kitap ve Yaymevi. Ankara.

8. INGALDI M., ROSAK-SZYROCKA J., JAGUSIAK-KocIK M. 2012. Service Quality in the Point of the Mass Nutrition. Chapter 1. W: Toyotarity. Quality of Services Assessment According to BOST Method. Monography. Editing and Scientific Elaboration BORKOWSKI S., INGALDI M. Faculty of Logistics, University of Maribor. Celje.
9. KonstanciaK M., JagusiaK-KociK M. 2012. Quality Control in the Company Processing the Metallurgical Wastes. Chapter 5. W: Quality of Materials. Monography. Editing and Scientific Elaboration BORKOWSKI S., KlimeCKa-Tatar D. Oficyna Wydawnicza Stowarzyszenia Menedżerów Jakości i Produkcji. Częstochowa. 